\title{
Production Performance of Chicken under Farmers' Management and Their Roles at Urban Household Economy in Southern Ethiopia
}

\author{
Yonas Kejela \\ Department of Animal Science, College of Agriculture and Natural Resource, Jinka University, Jinka, Ethiopia \\ Email:ykejela@gmail.com
}

How to cite this paper: Kejela, Y. (2020) Production Performance of Chicken under Farmers' Management and Their Roles at Urban Household Economy in Southern Ethiopia. Agricultural Sciences, 11, 178-190. https://doi.org/10.4236/as.2020.112011

Received: January 15, 2020

Accepted: February 16, 2020

Published: February 19, 2020

Copyright $\odot 2020$ by author(s) and Scientific Research Publishing Inc. This work is licensed under the Creative Commons Attribution International License (CC BY 4.0).

http://creativecommons.org/licenses/by/4.0/

\section{(c) (i) Open Access}

\begin{abstract}
This study was conducted to assess production performance of chicken under farmers' management and their roles in the household economy of local and exotic chickens reared at Yirgalem and Hawassa towns of Southern Ethiopia. Purposive sampling method was used for selecting the respondents. Totally, 180 respondents were selected based on their experience in chicken production. The study indicates that the average number of eggs set for incubation was $10.05 \pm 0.81$ of which the hatchability was $8.42 \pm 1.19$ eggs. The age at first egg laying for the native chickens raised at Hawassa and Yirgalem towns was $6.31 \pm 0.53$ and $6.10 \pm 0.30$ months respectively with differences recorded both within and between the locations. The age at first egg laying of the Sasso hens was $5.24 \pm 0.43$ months while the age at first egg lay for Bovans was 5.37 \pm 0.49 months. The difference was observed $(\mathrm{P}<0.05)$ across the studied locations. The values were lower when compared to those of the native chickens. It was also observed that the contributions of the exotic chickens to the livelihood and food security of the rearers were insignificant. It was concluded from this study that the exotic chickens in the study areas performed fairly well and could do so further if they are provided with better health care, scientific nutrition and management.
\end{abstract}

\section{Keywords}

Exotic and Local Chickens, Households' Economy, Performance, Southern Ethiopia

\section{Introduction}

Poultry includes all domestic birds reared for the purpose of food production 
(meat and eggs). However, the term "poultry" production under Ethiopian context is synonymous with chicken production [1]. According to [2] major proportion of chickens reared in the country are of indigenous types (95.86\%) with a minuscule number accounting for the crossbreds (2.79\%) and exotic chickens (1.35\%).

It is believed that the improved breeds of chickens were introduced to Ethiopia by the missionaries sometimes in the mid decades of the last century [3]. In a report of a study by [4] it was indicated that the exotic chicken such as Isa Brown, Bovans Brown and Potchefstroom Koekoek were distributed to smallholder farmers of the Oromia region. Similarly [5] also reported that the private chicken farms (Ethio-chicken poultry farm) distributed 42-day-old cockerels and pullets to the farmers of Wolaitta Zone in Southern Nations Nationalities and peoples Region state (SNNPRs) state and he also reported that the egg production and overall productive performances of exotic (Sasso) chickens were better than the indigenous chickens. Findings of a study by [4] also indicated that the exotic chicken such as Isa Brown, Bovans Brown and Potchefstroom Koekoek are good producers especially under farmers' management condition in Oromia region. Similarly, [6] also reported that Rhode Island Red (RIR) chickens have shown better production performance in Cheha woreda. In general, [7] concluded that exotic breed and cross breed chicken can produce a large number of eggs in the presence of an adequate amount of feed.

In terms of contribution of the chicken to the household income, [8] reported that the income from poultry made an important contribution to the average household income of Tigray, Amhara, Oromia and SNNPRs, and the Addis Ababa city administration dwellers. This contribution was more important in the peri-urban areas of Addis Ababa (38.4\%) than in the other sub-national zones. Across the sample households, the contribution of poultry to the total household income of all sub-national zones is $29.5 \%$; of these, contribution of poultry income to the households in SNNP is $22.87 \%$.

Since different exotic and crossbred chickens are distributed in the different parts of urban and peri-urban areas of the country. Performance evaluation of the poultry and their contribution to the household economy in the urban areas were rarely studied. Therefore, this study was conducted to evaluate production performance of different breeds of chicken and their roles in the household economy in the Hawassa and Yirgalem towns of southern Ethiopia.

\section{Materials and Methodology}

\subsection{Description of the Study Area}

The study was conducted in Hawassa city $\left(7^{\circ} 03^{\prime}\right.$ latitude North and $38^{\circ} 28^{\prime}$ longitude East at the elevation of the 1708 meters above sea level (m.a.s.l.) and Yirgalem town (latitude and longitude of $6^{\circ} 45^{\prime} \mathrm{N} 38^{\circ} 25^{\prime} \mathrm{E}$ ) and an elevation of 1776 m.a.s.l. Both the locations are situated in the Sidama zone of the SNNPRs region of southern Ethiopia [9]. 


\subsection{Sampling Techniques and Sample Size}

Purposive sampling process was used. From the 8 sub-cities of Hawassa, 3 subcities were selected purposively based on the chicken populations of the area and as suggested by the authorities of the Bureau of Agriculture. Two kebeles were purposively selected based on the chicken population. Furthermore, the respondents were selected based on their experience in chicken production and willingness to participate in the survey. While from Yirgalem town which has 9 kebeles, the 4 kebeles were selected purposively based on the above mentioned criteria. Among the selected kebeles, it was also purposively identified the people who have both local and exotic breed species in totally five and more chickens. In general, according to [10] from the identified individuals $20 \%$ (180 respondents) were purposively selected for the survey work.

\subsection{Data Collection Procedure}

The study encompassed semi-structured questioners. The questioner was pre-tested by key informants such as traditional poultry rearers and selected poultry owners before to gather information on performance of chicken (such as Hatching and hatchability, Age at first laying, Age of slaughter, and Weight of adult chicken) and also their roles on households' economy.

\subsection{Statistical Analysis}

The qualitative and quantitative data collected from survey were analyzed using SPSS version 16 [11]. The means of the quantitative traits were compared using Duncan Multiple Range Test, while two-way ANOVA was used to compare the values across the two studied locations. The values were considered significant at $5 \%$ levels.

\section{Results}

\subsection{Socio-Demography and Economy of Respondents}

As indicated in Table 1, the majority of the respondents of the study areas were females. Table 1 also indicates the average age of the respondents in both areas. Most of the respondents were traders followed by the government employees. Of the interviewed respondents most of them owned houses.

\subsection{Sources of Income for Respondents of Study Areas}

Furthermore, findings from Figure 1, indicated that most of the respondents were traders followed by salaried people. In this study, selling poultry and its products as the sources of income holds a little place (2\%) and this shows that there is no well-organized strategy on rearing chicken for the purpose of or to use as the sources of income rather than using for consumption during ceremonies, holidays and using for feeding their children daily. But, the selling poultry and its product were significantly $(\mathrm{P}<0.05)$ higher in Hawassa town than Yirgalem. 
Table 1. Socio-demography of the respondents in study areas $(\mathrm{N}=180)$.

\begin{tabular}{|c|c|c|c|c|}
\hline \multirow{2}{*}{ Variables } & \multicolumn{3}{|c|}{ Location } & \multirow{2}{*}{$\begin{array}{c}\text { Sig. at } \\
(\mathrm{p}<0.05)\end{array}$} \\
\hline & $\mathrm{Hw}$ & Yr & Mean & \\
\hline \multicolumn{5}{|l|}{ Sex of respondents } \\
\hline Male & 45.6 & 43.3 & 44.4 & \\
\hline Female & 54.4 & 56.7 & 55.6 & \\
\hline $\begin{array}{l}\text { Av. Age of respondents (year) } \\
(\text { Mean } \pm \text { SD.) }\end{array}$ & $43.7 \pm 11.94$ & $41.43 \pm 10.18$ & $42.57 \pm 11.12$ & \\
\hline \multicolumn{5}{|c|}{ Occupation of the respondents in the house (\%) } \\
\hline Crop-livestock farming & 0 & 14.4 & 7.2 & 0.0000 \\
\hline Local trader & 30.0 & 32.2 & 31.1 & \\
\hline Government employee & 32.2 & 25.6 & 28.9 & \\
\hline Self-employee & 17.8 & 4.4 & 11.1 & \\
\hline Retired & 8.9 & 6.7 & 7.8 & \\
\hline Housewife & 11.1 & 16.7 & 13.9 & \\
\hline \multicolumn{5}{|l|}{ Land ownership (\%) } \\
\hline Rent house & 37.8 & 25.6 & 31.7 & \\
\hline Owned house & 62.2 & 74.4 & 68.7 & \\
\hline
\end{tabular}

$\mathrm{Hw}=$ Hawassa, $\mathrm{Yr}=$ Yirgalem.

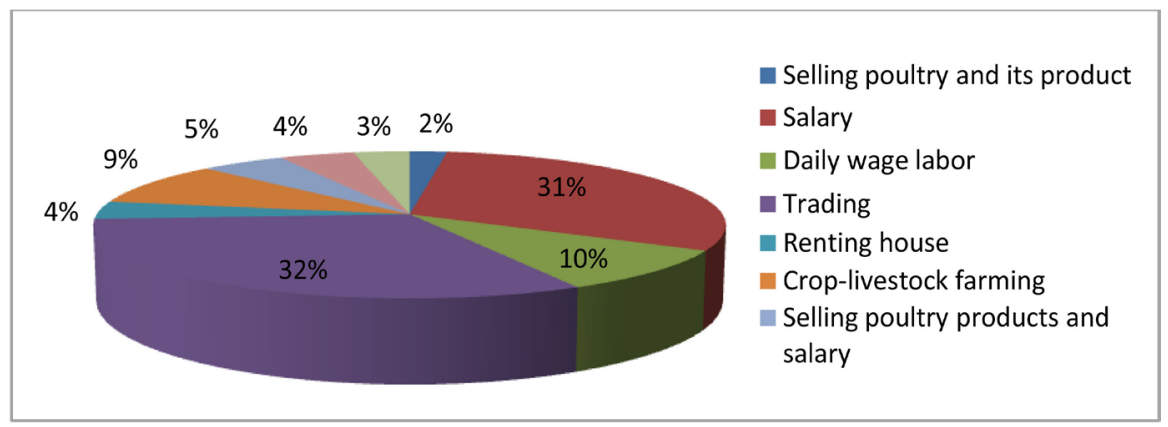

Figure 1. Source of income for respondents of study areas.

\subsection{Purpose of Keeping Chicken in the Study Areas}

The findings from Table 2 indicate that most of the respondents (irrespective of the study areas) rear chicken for their home consumption. This is closely followed by rearing the chickens for both home consumption and selling the extra products for some sort of income. This indicates that most of the rearers are subsistence farmers and their family income is not solely dependent on income from poultry related activities.

The results showed that chicken and eggs are primordially used for in house consumption which is expected to have positive effect on the health of the children, nursing mothers, old and infirm members of the family.

Differences were also observed in the selling of poultry products among the study areas which was higher in Hawassa, this might be ascribed to two main 
reasons i.e. the people in Hawassa are mostly dependent on purchasing food items from the market, while it is not so at Yirgalem. And also due to lack of space around their homes which deter them from maintaining a kitchen garden. The other reason being high demand for poultry products and established marketing system at Hawassa when compared to Yirgalem.

\subsection{Hatching and Hatchability Chicken in Study Areas}

The findings from (Table 3) indicates that most of the respondents did not keep

Table 2. Purpose of rearing the chicken in the study areas $(\mathrm{N}=180)$.

\begin{tabular}{|c|c|c|c|c|}
\hline \multirow{2}{*}{ Variables } & \multicolumn{2}{|c|}{ Location } & \multirow[t]{2}{*}{ Total } & \multirow{2}{*}{$\begin{array}{c}\text { Sig. at } \\
(\mathrm{P}<0.05)\end{array}$} \\
\hline & $\mathrm{Hw}$ & Yr & & \\
\hline Purpose of keeping chicken (\%) & & & & 0.03 \\
\hline For meat consumption & 8.9 & 6.7 & 7.8 & \\
\hline Live chicken for sale & 2.2 & 0 & 1.1 & \\
\hline Egg for consumption & 17.8 & 5.6 & 11.7 & \\
\hline Egg for sale & 13.3 & 6.7 & 10.1 & \\
\hline Egg for consumption and for sale & 22.2 & 25.8 & 24.0 & \\
\hline For meat and egg consumption and egg for sale & 7.8 & 10.1 & 8.9 & \\
\hline For meat and egg consumption & 27.8 & 44.9 & 36.3 & \\
\hline
\end{tabular}

$\mathrm{Hw}=$ Hawassa, $\mathrm{Yr}=$ Yirgalem.

Table 3. Hatching and hatchability performance of the chicken in the study areas $(\mathrm{N}=180)$.

\begin{tabular}{|c|c|c|c|c|}
\hline \multirow{2}{*}{ Variables } & \multicolumn{3}{|c|}{ Location } & \multirow{2}{*}{$\left(\chi^{2}<0.05\right)$} \\
\hline & $\mathrm{Hw}$ & Yr & Mean & \\
\hline Hatching of chicks (\%) & & & & 0.280 \\
\hline Yes & 33.3 & 41.1 & 37.2 & \\
\hline No & 66.7 & 58.9 & 62.8 & \\
\hline $\begin{array}{l}\text { Average no. of egg set for incubation } \\
(\text { Mean } \pm S D .)^{*}\end{array}$ & $10.06 \pm 1.03$ & $10.04 \pm 0.64$ & $10.05 \pm 0.81$ & 0.925 \\
\hline $\begin{array}{l}\text { Average no. of chicks hatched per brooding } \\
\qquad(\text { Mean } \pm \text { SD. })^{*}\end{array}$ & $8.34 \pm 1.41$ & $8.48 \pm 1.03$ & $8.42 \pm 1.19$ & 0.605 \\
\hline Reason for not using natural breeding (\%) & & & & 0.000 \\
\hline Giving priority to egg & 43.3 & 45.3 & 44.2 & \\
\hline Predator and disease & 8.3 & 52.8 & 29.2 & \\
\hline Have access to buy replacement stock & 10.0 & 0 & 5.3 & \\
\hline My hen do not brood & 38.3 & 1.9 & 21.2 & \\
\hline Interval of egg laying for exotic breed (\%) & & & & 0.507 \\
\hline Every day & 31 & 31.1 & 31.1 & \\
\hline After one day gap & 38 & 29.5 & 34.1 & \\
\hline Every day but sometimes they escape a day & 31 & 39.3 & 34.8 & \\
\hline
\end{tabular}


the eggs for hatching purpose, this was observed in both study areas and the significant $\left(\chi^{2}<0.05\right)$ variation was observed on the reason on why the respondents are not used the natural breeding. The study further indicated that the average numbers of eggs incubated did not vary across the study area and neither did the number of chicks hatched did not vary across the studied locations. This is in line with the observations where the respondents had indicated that they rear the chickens for home consumption of eggs and meat. The respondents from Yirgalem also pointed out that predatory and disease related problems (towards the chicks) were the reason for not hatching the eggs. While, many of the respondents from Hawassa pointed out that broodiness is a problem in the chickens reared at Hawassa. The results also indicate that the exotic chicken lay eggs every day while most of the respondents from Yirgalem pointed out that sometimes the exotic breeds skip egg laying however in most of the days they lay eggs daily.

\subsection{Age at First Laying of Local and Exotic Chickens of the Study Areas}

The results pertaining to the age at first egg lay varied across the different ecotypes with the native chickens laying eggs later when compared to the exotic genotypes; however, there was no variation within the exotic genotypes when it comes for the trait. There were also differences across the locations for particular ecotypes with the native chickens reared at Hawassa laying eggs later than those reared at Yirgalem. The variation observed could be due to the management and genetic make-up of the chickens.

The results pertaining to the clutch length varied across the genotypes and across the places where the chickens are reared. The clutch length was highest among the Bovans Brown chickens followed by the native and Sasso. Differences $(\mathrm{P}<0.05)$ were also observed across the locations with highest at Yirgalem when compared to those reared at Hawassa.

\subsection{Age of Slaughter of Local and Exotic Chickens of the Study Areas}

The results presented in (Table 4) also indicated that the average slaughter age of the chickens varied across the genotypes with the slaughter age of the native chickens being higher $(\mathrm{P}<0.05)$ when compared to the exotic ecotypes. The findings also indicated that the Sasso chickens had a higher growth rate and the slaughter age was the lowest $(\mathrm{P}<0.05)$ when compared to the other ecotypes.

\subsection{Weight of Adult Local and Exotic Chickens of the Study Areas}

The results pertaining to the weight of the cocks and hens reared in the two studied locations indicated that there was variation across the genotypes with the highest weight being observed among the Sasso types followed by the Bovans Brown (with no differences across the two genotypes) and the least among the 
Table 4. Performances of chicken (Mean \pm SD.) across the studied locations.

\begin{tabular}{|c|c|c|c|c|}
\hline \multirow[b]{2}{*}{ Parameter } & \multirow[b]{2}{*}{ Location } & \multicolumn{3}{|c|}{ Breed types and their performance } \\
\hline & & $\begin{array}{c}\text { Local } \\
(\mathrm{N}=85)\end{array}$ & $\begin{array}{c}\text { Sasso } \\
(\mathrm{N}=94)\end{array}$ & $\begin{array}{l}\text { Bovans brown } \\
(\mathrm{N}=38)\end{array}$ \\
\hline \multirow{3}{*}{$\begin{array}{c}\text { Av. age of first laying for } \\
\text { chickens (month) (Mean } \pm \text { SD) }\end{array}$} & $\mathrm{Hw}$ & $6.31 \pm 0.53^{* b}$ & $5.22 \pm 0.42^{\mathrm{a}}$ & $5.28 \pm 0.46^{\mathrm{a}}$ \\
\hline & $\mathrm{Yr}$ & $6.10 \pm 0.30^{\mathrm{b}}$ & $5.27 \pm 0.47^{\mathrm{a}}$ & $5.47 \pm 0.51^{\mathrm{a}}$ \\
\hline & Total & $6.19 \pm 0.42$ & $5.24 \pm 0.43$ & $5.37 \pm 0.49$ \\
\hline \multirow{3}{*}{$\begin{array}{l}\text { Slaughter age for chicken } \\
\text { (month) }(\text { Mean } \pm \text { SD) }\end{array}$} & $\mathrm{Hw}$ & $7.03 \pm 0.57^{\mathrm{b}}$ & $5.84 \pm 0.47^{\mathrm{a}}$ & $6.05 \pm 0.497^{\mathrm{a}}$ \\
\hline & Yr & $7.10 \pm 0.36^{c}$ & $5.82 \pm 0.49^{\mathrm{a}}$ & $6.12 \pm 0.48^{\mathrm{b}}$ \\
\hline & Total & $7.07 \pm 0.46$ & $5.83 \pm 0.48$ & $6.08 \pm 0.49$ \\
\hline \multirow{3}{*}{$\begin{array}{l}\text { Weight of maturecock }(\mathrm{Kg}) \\
\qquad(\text { Mean } \pm \mathrm{SD})\end{array}$} & $\mathrm{Hw}$ & $2.01 \pm 0.27^{\mathrm{a}}$ & $3.02 \pm 0.34^{\mathrm{b}}$ & $2.92 \pm 0.41^{\mathrm{b}}$ \\
\hline & Yr & $2.00 \pm 0.26^{\mathrm{a}}$ & $2.96 \pm 0.28^{\mathrm{b}}$ & $2.89 \pm 0.42^{\mathrm{b}}$ \\
\hline & Total & $2.00 \pm 0.26$ & $2.99 \pm 0.31$ & $2.91 \pm 0.41$ \\
\hline \multirow{3}{*}{$\begin{array}{l}\text { Weight of laying hen } \\
\text { (>20 weeks age })\end{array}$} & $\mathrm{Hw}$ & $1.81 \pm 0.19^{\mathrm{a}}$ & $2.91 \pm 0.38^{* c}$ & $2.69 \pm 0.19^{\mathrm{b}}$ \\
\hline & Yr & $1.80 \pm 0.16^{\mathrm{a}}$ & $2.73 \pm 0.39^{\mathrm{b}}$ & $2.61 \pm 0.28^{\mathrm{b}}$ \\
\hline & Total & $1.80 \pm 0.17$ & $2.82 \pm 0.39$ & $2.65 \pm 0.24$ \\
\hline
\end{tabular}

$\mathrm{Hw}=$ Hawassa, $\mathrm{Yr}=$ Yirgalem, ${ }^{\mathrm{a}, \mathrm{b}, \mathrm{c}} \mathrm{Means}$ with different superscripts across row (breeds) are significantly different $(\mathrm{P}<0.05)$.

natives. Variations were also recorded among the weight of the hens. The values were highest among the Sasso, Bovans Brown and native in the respective order. The length of brooding was also longest among the Sasso and Bovans Brown with the lowest amongst the native chickens. Variations were also observed across the locations with the highest $(\mathrm{P}<0.05)$ duration recorded at Hawassa, while the reverse was true $(\mathrm{P}<0.05)$ for the Sasso and Bovans Brown where the recorded values were higher at Yirgalem.

\section{Discussions}

\subsection{Socio-Demography and Economy of the Respondents}

The socio-demographic survey results (Table 1) indicated that poultry rearing is predominantly being carried out by people of age $(42.57 \pm 11.12)$, this is in consonance with the observations of [12] from a study at Dale, Wonsho and Lokka Abaya Woredas and more recently by [13]. The middle age group of the people are mostly working class and educated individuals and hence are unlike hobbyists (people of lower or aged groups) are expected to take the profession seriously if they are properly trained and encouraged [13].

\subsection{Source of Income for Respondents of Study Areas}

The results of the present study regarding the source of the income are in close accordance with the findings of [14] from Assosa district. This is characteristics of urban poultry farming as similar findings have also been reported by [13] 
from Addis Ababa. The results are quite encouraging as money earned from primary sources can be used for purchase of farm inputs viz. feed, medicine and also repair of poultry houses and equipment.

\subsection{Purpose of Keeping Chicken in the Study Areas}

The results showed that chicken and eggs are primordially used for in house consumption which is expected to have positive effect on the health of the children, nursing mothers, old and infirm members of the family. The observations are in close accordance with those of [15] and [16]. Besides the same eggs and chickens are also help in cementing social ties besides as a source of ready cash in case of emergency [3]. Differences were also observed in the selling of poultry products among the study areas which was higher in Hawassa, this might be ascribed to two main reasons i.e. the people in Hawassa are mostly dependent on purchasing food items from the market, while it is not so at Yirgalem, similar observations have also been recorded by [17]. And also due to lack of space around their homes which deter them from maintaining a kitchen garden. The other reason being high demand for poultry products and established marketing system at Hawassa when compared to Yirgalem, this too is in accordance with those of [18] who reported that demand of poultry products usually are linked with the marketing (especially in urban and peri-urban areas). The findings are in agreement with the results of [19] and [20] who reported that poultry consumption is correlated with the wealth status of the rearers.

The results pertaining to the purpose of rearing chickens are in close accordance with the observations of [16] from Tigray region. The observations are also in line with the reports of [15] from a study about poultry rearers of Gonder town. Rearing chickens for home consumption ensures adequate consumption of protein among the household members [21]. It has also been reported by [22] that consumption of chicken meat and eggs also help pregnant mother for health and growth of the foetus. Some of the respondents also indicated that they rear chickens for income generation which is in accordance with the observations of [16], who reported that the proceedings of sales from poultry products are generally used by the women to carter to daily needs of the house.

\subsection{Hatching and Hatchability of Chicken in the Study Areas}

The findings pertaining to the practice of rearing chickens for replacement stock (Table 3) are much lower than those reported from rural areas of the country [23]. The observations concur with those of [15] from urban areas of Northern Gondar. This might be ascribed to availability of the replacement stock in the market besides those from local governmental and nongovernmental organizations which have their offices in the towns.

The average number of eggs used for incubation is too similar to those reported by [15]; however, this can vary across the strains of chickens [24]. The number of eggs set for incubation per hen depends on availability of eggs, size of 
eggs and size of broody hen and the maternal instinct of the broody hen [25]; hence improved strains of birds have larger body size and therefore can incubate more number of eggs contrary to those of the native strains. The respondents should be made aware of the importance of proper storage prior to incubating facilities so that the hens are comfortable with high hatching percentages [26]. The hatching percentage observed was higher than those reported by [27] from Sidama zone Southern part of Ethiopia. However, there are still scopes to improve the same by providing adequate feed and incubation management to the broody hens.

\subsection{Age at First Laying of Local and Exotic Chickens of the Study Areas}

The age of first egg lay (Table 4) coincides with the maturity of the birds which is in accordance with those reported by [3]. Lower age at maturity culminates with proper feeding and management as the trait is lowly heritable [20]. The trait however varies across the types of chickens with native chickens maturing later when compared to their exotic counterparts [20].

The age at first egg of the Sasso, Koekoeck and Bovans are in accordance with those of [28] and [20] from East Shewa. The findings of a study conducted by [29] have however indicated that the exotic chickens (especially Koekoeck breed) matured later than they normally should do; this might be ascribed to lack of balanced feed besides managerial issues.

\subsection{Age of Slaughter of Local and Exotic Chickens of the Study Areas}

The results pertaining to the age at slaughter of the studied chickens are presented in Table 4 . The results indicated that the age at slaughter varied across the studied genotypes favoring the exotic chickens. These observations concur with the results of [5] from Southern region of Ethiopia. Lower age at slaughter has its own economic importance as such birds are expected to consume less feed and the business turnover is faster thereby lowering the overall risk [30]. The differences in slaughter age might be ascribed to the genetic makeup of the chickens. While the native chickens have been selected for their adaptive traits compromising the productive parameters, the reverse was true for the exotic chickens [5].

The age at slaughter for the native chickens were, however, lower than those reported by [31], this might be ascribed to their genetic makeup and several non-genetic factors [32]. The slaughtering age is correlated with growth which in turn is influenced by the feed availability besides other environmental factors. Hence holistic improvement of the non-genetic factors can help lower the age at slaughter of both the native and exotic genotypes [33].

\subsection{Weight of Adult Local and Exotic Chickens of the Study Areas}

The results pertaining to the weight of the chickens at maturity (Table 4) of the 
native chickens find similarity with the reports of [34] who reported that the average weight of the indigenous type cocks reared North-West Ethiopia was 2.05 $\mathrm{Kg}$. The reports are however lower $(1.67 \mathrm{Kg})$ than those reported by [12] from Dale wereda, Southern Ethiopia. The results pertaining to the mature weight of the Sasso and Bovans brown cocks were similar with the [5] from Southern Ethiopia who reported that the average weight of Sasso cocks were $2.98 \pm 0.70$ Kg.

The results pertaining to the weight of the native hens ( $>20$ weeks old) was higher than those observed from the findings of [35] from South West Showa and Gurage zone of Ethiopia and [36] from Cameroon. The results for the body weight of the Sasso hens are in accordance with the findings of [5] from Southern Ethiopia who reported that the average weight of the Sasso hens were $2.73 \pm$ $0.53 \mathrm{Kg}$. The weight of the hens of Bovans Brown as recorded in this study was higher than those observed in this study [28].

Body weight at maturity is an important trait which is indicative of the $\mathrm{G} \times \mathrm{E}$ (genotype environmental interaction) as chickens with optimal mature weight are those which have adapted to the specific environment [36]. [35] also suggested that the difference of the body weight on the chicken attributed due to genetic factors. Optimal weight at maturity if reached at an early age ensures that the managerial costs are low and hence adds on to the profit of the venture [30].

\section{Conclusion}

The overall results of the present study reveal that the performance of both local and exotic chicken under farmers' management in the study areas was fairly well. However, the performance of the exotic chicken breeds (Sasso and Bovans Brown) is well in the study area, their contribution to the income of the households is very low and there are no any works that have been done on improved managements to boost-up the production of chicken for livelihoods and their income. Thus, improving the management system such as improved feeding, housing and health care extension packages could be a better strategy to increase the egg production potential of indigenous and exotic chickens under farmers' management condition.

\section{Acknowledgements}

The author acknowledges the assistance received from staff members of Department of Animal Sciences, Jinka University, Hawassa and Yirgalem city of livestock and fishery office and householders for giving valuable information during survey and data collection.

\section{Conflicts of Interest}

The author declares no conflicts of interest regarding the publication of this paper. 


\section{References}

[1] Central Statistical Agency (CSA) (2012) Agricultural Sample Survey 2011/12. Report on Livestock and Livestock Characteristics (Volume 2). Addis Ababa.

[2] Central Statistical Agency (CSA) (2015) Agricultural Sample Survey Vol. II. Statistical Bulletin No. 578. CSA, Addis Ababa.

[3] Meseret, M. (2010) Characterization of Village Chicken Production and Marketing System in Gomma Wereda, Jimma Zone, Ethiopia. An M.Sc. Thesis Presented to School of Graduate Studies of Jimma University, Jimma, 110.

[4] Tadesse, D., Singh, H., Mengistu, A., Esatu, E. and Tadelle, D. (2013) Study on Productive Performances and Egg Quality Traits of Exotic Chickens under Village Production System in East Shewa, Ethiopia. African Journal of Agricultural Research, 8, 1123-1128. https://doi.org/10.5897/AJAR2013.6987

[5] Aman, G., Addisu, J., Mebratu, A., Kebede, H.G., Bereket, Z. and Teklayohannes, B. (2017) Management Practices and Productive Performances of Sasso Chickens Breed under Village Production System in SNNPR, Ethiopia. Journal of Biology, Agriculture and Healthcare, 7, 120-135.

[6] Dirsha, D. (2009) Assessment of Village Rhode Island Red Chicken Management Practices in Cheha Woreda and Evaluation of Different Levels of Brewers Dried Grain on Growth Performance of the Chicks. A Thesis Submitted to the School of Graduate Studies of Haramaya University, Haramaya.

[7] Haftu, K. (2016) Exotic Chicken Status, Production Performance and Constraints in Ethiopia: A Review. Asian Journal of Poultry Science, 10, 30-39. https://doi.org/10.3923/ajpsaj.2016.30.39

[8] Alemayehu, G.S. (2017) Characterization of Scavenging and Intensive Chicken Production and Marketing System in Lume District, East Shoa Zone, Oromia Region State, Ethiopia. An M.Sc. Thesis, Haramaya University, Haramaya, 163.

[9] IPMS (2005) Dale Pilot Learning Woreda Diagnosis and Program Design. Addis Ababa, Ethiopia, 76.

https://cgspace.cgiar.org/bitstream/handle/10568/16755/Dale.pdf?sequence=1\&isAll owed $=\mathrm{y}$

[10] Kish, L. (1965) Survey Sampling. John Wiley and Sons, Inc., New York.

[11] Statistical Package for Social Sciences SPSS Inc. (2007) SPSS for Windows, Version 16.0. SPSS Inc., Chicago.

[12] Mekonnen, G. (2007) Characterization of Smallholder Poultry Production and Marketing System of Dale, Wonsho and Loka Abaya Weredas of Southern Ethiopia. M.sc. Thesis Presented to the School of Graduate Studies of Hawassa University, Hawassa, 111.

[13] Nebiyu, Y.A. (2016) Assessment of Urban Poultry Production Practices in Addis Ababa with Emphasis on Egg Production, Product Marketing, Feed Quality and Waste Management. PhD Dissertation, Addis Ababa University, Addis Ababa, 174.

[14] Nega, M., Aklilu, H.M. and Haimanot, D. (2016) Reproductive and Productive Performance of Poultry Kept in Rural, Peri-Urban and Urban Settings in Assosa District, Benishangul Gumuz Region, Western Ethiopia. Nature and Science, 14, 8-14.

[15] Wondu, M., Mehiret, M. and Berhan, T. (2013) Characterization of Urban Poultry Production System in Northern Gondar, Amhara Regional State, Ethiopia. Agriculture and Biology Journal of North America, 4, 192-198. https://doi.org/10.5251/abjna.2013.4.3.192.198 
[16] Alem, T.A., Yayneshet, T.G. and Aklilu, H.A. (2013) Socio-Economic Characteristics of Poultry Production in Lowland and Midland Agro-Ecology Zone of Central Tigray, Ethiopia. International Journal of Livestock Production, 5, 71-80. https://doi.org/10.5897/IJLP2013.0153

[17] Thomas, P.Z.M. (2013) An Evaluation of the Performance of Urban Agriculture in Addis Ababa City, Ethiopia. Research Journal of Agricultural and Environmental Management, 2, 51-57. http://www.apexjournal.org

[18] Gezahegn, A. (2009) Value Chain Analysis of Poultry Sector-HPAI in Ethiopia. A Report Submitted to IFPRI. December 2009.

[19] Bush, J. (2006) The Threat of Avian Flu Predicted Impacts on Rural Livelihoods in Southern Nation, Nationalities and Peoples Region (SNNPR), Ethiopia. The Food Economy Group, May, 2006.

[20] Matiwos, H., Negas, A. and Solomon, D. (2013) Evaluation of Socio-Economic Role and Challenges of Rural Poultry Keeping in Nole Kabba Woreda, Western Wollega, Ethiopia. Direct Research Journal of Agriculture and Food Science, 1, 33-39.

[21] Ahuja, V. (2004) Livestock and Livelihoods: Challenges and Opportunities for Asia in the Emerging Market Environment, National Dairy Development Board, India and Pro-Poor Livestock Policy Facility (South Asia Hub) of FAO.

[22] Ruxton, C. (2013) Value of Eggs during Pregnancy and Early Childhood. Nursing Standard, 27, 41-50. https://doi.org/10.7748/ns2013.02.27.24.41.e7343

[23] Habtamu, M., Bereket, K. and Binyman, A. (2014) Assessment of the Production Potential and Constraints of Chicken in Some Chagni Town, Awi-Administrative Zone, Amhara Region, Ethiopia. International Journal of Agricultural Research and Reviews, 2, 99-107.

[24] King'ori, A.M. (2011) Review of the Factors That Influence Egg Fertility and Hatchability in Poultry. International Journal of Poultry Science, 10, 483-492. https://doi.org/10.3923/ijps.2011.483.492

[25] Matiwos, H. (2012) Study on Production Practices and Production Performance of Indigenous and Exotic Chicken Breeds under Rural Household Condition in Nole Kabba Woreda, Western Wollega, Ethiopia. An M.Sc. Thesis, Haramaya University, Haramaya, 147.

[26] Ewonetu, K. (2016) Effect of Egg Storage Periods on Egg Weight Loss, Hatchability and Growth Performances of Brooder and Grower Leghorn Chicken. IOSR Journal of Agriculture and Veterinary Science, 9, 75-79.

[27] Feleke, A., Teka, T. and Abeba, D. (2015) Challenges and Opportunities of Village Poultry Production in Arbegona Woreda, Sidama Zone, Southern Ethiopia. Developing Country Studies, 5, 71-78.

[28] Desalew, T. (2012) Management Practices, Productive Performances and Egg Quality Traits of Exotic Chickens under Village Production System in East Shewa, Ethiopia. An M.Sc. Thesis, Addis Ababa University, Debre Zeit, 70.

[29] Getu, A., Fantahun, T., Hailu, A. and Halie, B. (2017) Performance Evaluation of the Disseminated Exotic Chickens in Three Agro-Ecologies of North Gondar Zone, Ethiopia. Livestock Research for Rural Development, 29. http://www.lrrd.org/lrrd29/4/getu29073.htm

[30] Wright, D., Rubin, C., Schutz, K., Kerje, S., Kindmark, A., Brandström, H., Andersson, L., Pizzari, T. and Jensen, P. (2012) Onset of Sexual Maturity in Female Chickens Is Genetically Linked to Loci Associated with Fecundity and a Sexual Ornament. Reproduction in Domestic Animals, 47, 31-36. 
https://doi.org/10.1111/j.1439-0531.2011.01963.x

[31] Zereu, G. and Lijalem, T. (2016) Production and Reproduction Performance of Local Chicken Breeds and Their Marketing Practices in Wolaita Zone, Southern Ethiopia. African Journal of Agricultural Research, 11, 1531-1537. https://doi.org/10.5897/AJAR2015.10728

[32] Kor, A., Baspinar, E., Karaca, S. and Keskin, S. (2006) The Determination of Growth in Akkeci (White Goat) Female Kids by Various Growth Models. Czech Journal of Animal Science, 51, 110-116. https://doi.org/10.17221/3917-CJAS

[33] Padhi, M.K. (2016) Importance of Indigenous Breeds of Chicken for Rural Economy and Their Improvements for Higher Production Performance. Scientifica, 2016, Article ID: 2604685. https://doi.org/10.1155/2016/2604685

[34] Halima, H.M. (2007) Phenotypic and Genetic Characterization of Indigenous Chicken Populations in North-West Ethiopia. PhD Thesis, Submitted to the Faculty of Natural and Agricultural Sciences Department of Animal, Wildlife and Grassland Sciences, University of the Free State, Bloemfontein, 186.

[35] Emebet, M.B. (2015) Phenotyipc and Genetic Characterization of Indgenous Chicken in Southwest Showa and Gurage Zones of Ethiopia. PhD Dissertation, Addis Ababa University, Addis Ababa, 127.

[36] Mube, H.K., Kana, J.R., Tadondjou, C.D., Yemdjie, D.D., Manjeli, Y.M. and Teguia, A. (2014) Laying Performances and Egg Quality of Local Barred Hens under Improved Conditions in Cameroon. Journal of Applied Biosciences, 74, 6157-6163. https://doi.org/10.4314/jab.v74i1.8 